\title{
Physical performance of particleboards using Castor oil-based adhesive
}

\author{
Luciano D. Varanda ${ }^{1}$, Fábio M. Yamaji ${ }^{1}$, Luís R. O. Santos ${ }^{1}$, \\ Diogo A. L. Silva², André L. Christoforo ${ }^{3} \&$ Francisco A. R. Lahr ${ }^{4}$
}

\begin{abstract}
${ }^{1}$ Universidade Federal de São Carlos/Departamento de Ciências Ambientais/Programa de Pós-Graduação em Planejamento e Uso de Recursos Renováveis. Sorocaba, SP. E-mail: lu.varanda@hotmail.com - ORCID: 0000-0003-1193-4944; fmyamaji@ufscar.br - ORCID: 0000-0002-0908-8163; lrtatui@gmail.com ORCID: 0000-0003-4649-7852

${ }^{2}$ Universidade Federal de São Carlos/Departamento de Engenharia de Produção de Sorocaba. Sorocaba, SP. E-mail: diogo.apls@ufscar.br - ORCID: 0000-0002-7514-7467

${ }^{3}$ Universidade Federal de São Carlos/Departamento de Engenharia Civil. São Carlos, SP. E-mail: alchristoforo@gmail.com (Corresponding author) ORCID: 0000-0002-4066-080X

${ }^{4}$ Universidade de São Paulo/Escola de Engenharia de São Carlos/Departamento de Engenharia de Estruturas. São Carlos, SP. E-mail: frocco@sc.usp.br ORCID: 0000-0002-3510-8498
\end{abstract}

\section{Key words:}

particleboards

Pinus elliottii

oat hulls

analysis of variance (ANOVA)

wastes

\begin{abstract}
A B S T R A C T
Reconstituted wood panels are widely used in various branches of the wood industry, such as in the furniture sectors and various segments of urban and rural construction. In Brazil, agricultural and forestry residues are abundantly generated, making feasible the study, development and application of alternative and sustainable materials, produced from the use of these wastes. The aim of this study was to produce high-density homogenous panels with wood residues of Pinus elliottii and oat hulls (Avena sativa), pressed with two types of adhesive, castor oil-based polyurethane and melamine formaldehyde, and to evaluate the physical performance of these panels. The physical performance of the panels was evaluated based on the ABNT NBR 14810: 2006, ANSI A208.1: 1999 and BS EN 312: 2003 standards. Analysis of variance (ANOVA) was performed to test the influence of the factors percentage of oat hull, percentage of adhesive and type of adhesive, and the interactions between these factors on the physical properties of the panels. The results indicated physical properties, in some treatments superior to the requirements stipulated by the consulted standards. It was concluded that the panels produced with the castor oil-based polyurethane adhesive showed better physical performance when compared with the panels produced with the melamine formaldehyde adhesive.
\end{abstract}

\section{Palavras-chave:}

painéis aglomerados

Pinus elliottii

casca de aveia análise de variância (ANOVA) resíduos

\section{Desempenho físico de painéis de partículas usando adesivo à base de óleo de mamona}

\begin{abstract}
R E S U M O
Os painéis de madeira reconstituída são muito empregados em vários ramos da indústria da madeira, como nos setores moveleiros e vários segmentos da construção civil urbana e rural. No Brasil são gerados resíduos agrícolas e florestais abundantemente, tornando viável o estudo, desenvolvimento e aplicação de materiais alternativos e sustentáveis, produzidos a partir do aproveitamento destes resíduos. O objetivo deste trabalho foi produzir painéis de partículas homogêneos de alta densidade, com resíduos de madeira de Pinus elliottii e casca de aveia (Avena sativa), prensados com dois tipos de adesivo, poliuretano à base de óleo de mamona e melamina formaldeído, e avaliar o desempenho físico destes painéis. $\mathrm{O}$ desempenho físico dos painéis foi avaliado com base nas normas ABNT NBR 14810:2006, ANSI A208.1:1999 e BS EN 312:2003. Foi realizado uma análise de variância (ANOVA) para testar a influência dos fatores percentual de casca de aveia, percentual de adesivo e tipo de adesivo, e as interações entre estes fatores nas propriedades físicas dos painéis. Os resultados apontaram propriedades físicas, em alguns tratamentos superiores aos requisitos estipulados por normas consultadas. Conclui-se que os painéis produzidos com o adesivo poliuretano à base de óleo de mamona apresentaram melhor desempenho físico, se comparado aos painéis produzidos com o adesivo melamina formaldeído.
\end{abstract}




\section{INTRODUCTION}

The development and characterization of new materials have been continuously experimented with applications of these materials, such as more versatile and efficient applications, reduction of energy costs and waste generation, lower environmental impacts and products with less impact on the planet (Silva et al., 2015).

The use and application of wood products have grown by leaps and bounds in recent years, not only in Brazil but throughout the world. Wood panels are the main raw material in a range of other wood product industries, such as flooring, furniture, packaging, shipbuilding and various construction segments. Brazilian consumption of wood-based panels increased by approximately $15.9 \%$ in 2017 compared with 2016, with billing increasing from 246 to 285 million dollars. The expansion and growth of the wood-based panel industries significantly increases the demand for raw materials, forcing the search for other materials (Varanda et al., 2014; Christoforo et al., 2016).

The generation of waste is significant in Brazil. In 2016, about 19.1 million cubic meters of wood-based waste were generated. In the same year, the Brazilian production of particleboards was approximately 3.0 million cubic meters (FAO, 2018).

Among these agroindustrial residues, the hull generated in the processing of the oat cereal has great potential, especially in relation to the amount of raw material that, according to Webster (1986), represents about $30 \%$ of the mass of the cereal. Brazilian production of oats was approximately $884,000 \mathrm{t}$ in 2016 , that is, approximately $265,000 \mathrm{t}$ of oat hulls were generated (IBGE, 2016).

Adhesive is an important component in the production of panels based on wood and its derivatives, which can represent up to $50 \%$ of the total cost of the panel. In relation to the melamine formaldehyde adhesive, it has intermediate physical and mechanical performance between the adhesives urea formaldehyde and phenol formaldehyde (Iwakiri, 2005). Polyurethane adhesives impart high moisture resistance, better physical and mechanical properties, compared with panels bonded with phenolic resins, in addition to not emitting formaldehyde (Ferro et al., 2016). Several studies have been developed with polyurethane adhesive based on castor oil, under alternative lignocellulosic materials for the production of particleboards (Varanda et al., 2013; Gava et al., 2015; Vidil et al., 2016; Cravo et al., 2017; Machado et al., 2017).

In this context, it justifies the study of alternative inputs in the production of particleboard panels. The aim of this study was to produce high-density homogenous particleboards with wood residues of Pinus elliottii and oat hulls (Avena sativa), subjected to pressure with two types of adhesives, polyurethane based on castor oil and melamine formaldehyde. In addition, it aimed to evaluate the physical performance of the panels (thickness swelling for 2 and $24 \mathrm{~h}$ period, water absorption for 2 and $24 \mathrm{~h}$ period, density and compaction ratio).

\section{Material ANd Methods}

This study was conducted at the University of São Paulo (USP), Campus of São Carlos, specifically in the Wood and
Timber Structures Laboratory (LaMEM), located at the Department of Structural Engineering (SET) of the São Carlos School of Engineering (EESC).

Particleboards were made using wood wastes of Pinus elliottii and wastes of oat hulls (Avena sativa). The wood of Pinus elliottii had an apparent density of $480 \mathrm{~kg} \mathrm{~m}^{-3}$ (12\% of humidity) and oat hulls material had an apparent density of $290 \mathrm{~kg} \mathrm{~m}^{-3}$ (12\% of humidity). Wood wastes of Pinus elliottii were obtained in the city of São Carlos, state of São Paulo. The oat hulls used were obtained from an industry in the sector, located in the city of Porto Alegre, Rio Grande do Sul State.

Two types of adhesives were used: polyurethane based on castor oil (PU) and melamine formaldehyde (MF). The PU adhesive was adopted due to its good performance obtained in previous studies, conducted at the LaMEM/SET, with wood panels (Bertolini et al., 2014; Macedo et al., 2015; Nascimento et al., 2017). This is an adhesive of mostly natural and renewable origin. The PU adhesive used is bicomponent type, at a ratio of 1:1 between prepolymer and polyol, with a solid content of $100 \%$. One of the components (polyol) is derived from vegetable oil, with a density of $1.10 \mathrm{~g} \mathrm{~cm}^{-3}$, and the other component (prepolymer) is the polyfunctional isocyanate, with density of $1.24 \mathrm{~g} \mathrm{~cm}^{-3}$.

Melamine formaldehyde adhesive was adopted because it is widely used in wood-based panels industries in Brazil, although its use is controlled and questionable in countries with strict environmental control because it emits formaldehyde, an undesirable substance that is harmful to human health (Samlaic, 1983). The melamine formaldehyde adhesive (MF) used showed the following physicochemical characteristics: $\mathrm{pH}$ at $25^{\circ} \mathrm{C}$ of 8.48 ; solid content $\left(3 \mathrm{H}\right.$ at $\left.105^{\circ} \mathrm{C}\right)$ of $71.28 \%$; density at $25^{\circ} \mathrm{C}$ of $1.26 \mathrm{~g} \mathrm{~cm}^{-3}$; Brookfield viscosity at $25^{\circ} \mathrm{C}$ of 756 centipoises and free formol equal to $0.19 \%$. The melamine formaldehyde adhesive (MF) had an addition of $1.5 \%$ ammonium sulfate, relative to the mass of the adhesive. The ammonium sulfate has the catalytic function, i.e., to accelerate the adhesive curing process. It was decided not to use paraffin because the MF adhesive shows good resistance to humidity.

From the preliminary tests, the experimental design was defined. It originated 20 treatments $(\operatorname{Tr})$ as shown in Table 1. For each of the 20 treatments (Tr), five identical particleboards were produced, totaling 100 particleboards. The panels produced had nominal dimensions of $280 \times 280 \times 10 \mathrm{~mm}$.

The particles of both materials were generated in a Wileytype mill, using a $2.8 \mathrm{~mm}$ aperture sieve. After the generation of the particles, their moisture content was determined in the oven at a temperature of $105 \pm 2{ }^{\circ} \mathrm{C}$.

The next step was the preparation and application of the resin. The particles of Pinus elliottii and oat hulls were generated in a mill. Then, the particles of both materials and the adhesive were weighed according to the stipulated amounts. Then, the particles and the adhesive were added in the blending equipment until the homogenization of these materials. The adhesive proportions used were 11 and $13 \%$ relative to the mass of the particles. The amount of particles used in each panel was defined from the density range (from 850 to $950 \mathrm{~kg} \mathrm{~m}^{-3}$ ) and from the volume adopted for the panels (nominal dimensions of $280 \times 280 \times 10 \mathrm{~mm}$ ). The particles and the adhesive remained in the glue for at least $5 \mathrm{~min}$. 
Table 1. Experimental design adopted

\begin{tabular}{|c|c|c|c|c|c|c|c|}
\hline Treatments (Tr) & $\% \mathrm{OH}$ & $\%$ Adhes & $\mathrm{TA}$ & Treatments (Tr) & $\% \mathrm{OH}$ & $\%$ Adhes & TA \\
\hline Tr1 & 0 & 11 & MF & Tr11 & 50 & 13 & MF \\
\hline Tr2 & 0 & 11 & PU & Tr12 & 50 & 13 & PU \\
\hline Tr3 & 0 & 13 & MF & Tr13 & 75 & 11 & MF \\
\hline Tr4 & 0 & 13 & PU & Tr14 & 75 & 11 & PU \\
\hline Tr5 & 25 & 11 & MF & Tr15 & 75 & 13 & MF \\
\hline Tr6 & 25 & 11 & PU & Tr16 & 75 & 13 & PU \\
\hline Tr7 & 25 & 13 & MF & Tr17 & 100 & 11 & MF \\
\hline Tr8 & 25 & 13 & PU & Tr18 & 100 & 11 & PU \\
\hline Tr9 & 50 & 11 & MF & Tr19 & 100 & 13 & MF \\
\hline Tr10 & 50 & 11 & PU & Tr20 & 100 & 13 & PU \\
\hline
\end{tabular}

Tr - Treatment; \% OH - Oat hulls percentage; \% Adhes - Adhesive percentage; TA - Type of adhesive; MF -Melamine formaldehyde adhesive; PU - Polyurethane adhesive based on castor oil

After complete homogenization of the adhesive with the particles, the mixture was prepressed in order to form the particle "mattress". It received a force of $1 \mathrm{kN}$, equivalent to a pressure of $0.013 \mathrm{MPa}$. The prepressing of the panel was carried out using a manual mechanical press, manufactured in-house.

Then, the particle "mattress" already preformed with a thickness of $2 \mathrm{~cm}$ (measured by a spacer) was sent to the press. The panels were pressed in a semiautomatic press, with a capacity of $800 \mathrm{kN}$ and a maximum temperature of $200{ }^{\circ} \mathrm{C}$. The pressing conditions used in this study were: $10 \mathrm{~min}$ time, 4 $\mathrm{MPa}$ pressure and temperatures of $100^{\circ} \mathrm{C}$ for the polyurethane adhesive based on castor oil, and $160{ }^{\circ} \mathrm{C}$ for the melamine formaldehyde adhesive. After pressing, all the panels produced were conditioned for at least $72 \mathrm{~h}$, aiming at the stabilization and complete cure of the adhesive. After the conditioning period, the panels were subjected to squaring and subsequent sectioning to remove the specimens. Initially about $10 \mathrm{~mm}$ were removed from each end of the panel, in a circular saw cutter. The panels had nominal dimensions of $260 \times 260 \times$ $10 \mathrm{~mm}$. From the squaring, the panels were sectioned in the dimensions of the specimens. A circular saw was used for the squaring and sectioning of the panels.

All physical characterization of the panels was performed according to the NBR 14810 standard (ABNT, 2006). All the results obtained in the tests were submitted to statistical analysis in order to evaluate if the factors and levels adopted in the experimental design had influence on the physical performance of the panels produced at a significance level of $5 \%$. The statistical analysis adopted was an analysis of variance (ANOVA), using Minitab ${ }^{\circledR}$ software, version 14.

Six samples were removed from each panel, so that it was possible to analyze different physical properties (thickness swelling for 2 and $24 \mathrm{~h}$ period, water absorption for 2 and $24 \mathrm{~h}$ period, density and compaction ratio), except the moisture content (MC). For this, a specimen was sampled for each of the 10 randomly selected panels, among the 100 panels produced, only to verify the average MC of the evaluated panels. The MC properties of the panels were not subjected to analysis of variance (ANOVA). It was done in factorial arrangement $(5 \times 2 \times 2)$ was used, corresponding to 5 fractions of particles, 2 percentages of adhesive and 2 types of adhesives. ANOVA had as null hypothesis $\left(\mathrm{H}_{0}\right)$ the equivalence of means between treatments, and non-equivalence as alternative hypothesis $\left(\mathrm{H}_{1}\right)$. Thus, $\mathrm{p}$-value of the test above the level of significance implies accepting $\mathrm{H}_{0}$, rejecting it otherwise.

\section{Results AND Discussion}

The results obtained for the physical properties of the panels were compared with the requirements established by the standards NBR 14810 (ABNT, 2006), A208.1 (ANSI, 1999) and EN 312 (BS, 2003).

The average moisture content of the panels evaluated was 9.2\%. The particleboards produced by Weber \& Iwakiri (2015) had a moisture content in the range of 7.3 to $9.0 \%$, that is, similar to the mean moisture content of the panels of this study. According to Iwakiri (2005), the ideal moisture content of the panels is below $10 \%$.

Table 2 shows the mean values (x) and coefficients of variation $(\mathrm{cv})$ of the physical properties of the panels.

In Table 2, 10 treatments $(2,4,6,8,10,12,14,16,18,20$, treatments produced with $\mathrm{PU}$ adhesive) showed a thickness swelling inferior to $8 \%$, meeting the requirement of the standard NBR 14810 (ABNT, 2006). For the thickness swelling property for $24 \mathrm{~h}$ period, nine treatments ( $\operatorname{Tr} 1$ to 4,6 to 8 , 12 and 20) had a swelling of less than $16 \%$, according to EN 312 (BS, 2003).

The water absorption properties (for 2 and $24 \mathrm{~h}$ periods) do not have requirements in any of the four standards consulted. For the water absorption property for $2 \mathrm{~h}$ period, the mean result obtained by Gava et al. (2015) is similar to the range of results obtained in this study. Particleboards produced by Fiorelli et al. (2015) exhibited water absorption of up to $69.8 \%$, i.e., higher than the results obtained here (water absorption in the range of 2.9 to $40.5 \%$ ). For the water absorption property for $24 \mathrm{~h}$ period, the values obtained in this study (water absorption in the range of 12.8 to $43.5 \%$ ) are similar to the mean value of $38.8 \%$ presented by Gava et al. (2015). This large variation of the physical properties is associated to the different materials used in the production of the panels, due to the incompatibility of these materials with the adhesives used and due to the pressing variables such as temperature, pressure and time (Iwakiri, 2005).

The density of the panels exhibited great variation among the evaluated treatments, with results in the range of 882 to $1066 \mathrm{~kg} \mathrm{~m}^{-3}$. All treatments showed high density (above $800 \mathrm{~kg} \mathrm{~m}^{-3}$ ). This variation was also observed in other studies, such as Bertolini et al. (2014), Fiorelli et al. (2015) and Gava et al. (2015). According to Iwakiri (2005), differences in the final density of the panel are associated with the material used in the respective process of manufacture, variables such as the moisture content of the particles and the differences in density between the particles used in the manufacture of such 
Table 2. Results of the physical properties of the panels

\begin{tabular}{|c|c|c|c|c|c|c|c|}
\hline \multirow{2}{*}{ Tr. } & \multirow{2}{*}{ Stat. } & TS $2 \mathrm{~h}$ & TS $24 \mathrm{~h}$ & WA $2 \mathrm{~h}$ & WA $24 \mathrm{~h}$ & \multirow{2}{*}{$\begin{array}{c}\text { D } \\
\left(\mathrm{kg} \mathrm{m}^{-3}\right)\end{array}$} & \multirow{2}{*}{ CR } \\
\hline & & \multicolumn{4}{|c|}{$(\%)$} & & \\
\hline \multirow{2}{*}{1} & $\overline{\mathrm{x}}$ & 12.2 & 14.5 & 30.3 & 37.4 & 882 & 1.84 \\
\hline & CV (\%) & 9.0 & 8.1 & 18.5 & 12.2 & 2.5 & 2.50 \\
\hline \multirow{2}{*}{2} & $\bar{x}$ & 7.6 & 12.7 & 12.5 & 29.2 & 892 & 1.86 \\
\hline & CV (\%) & 15.1 & 12.2 & 17.2 & 17.4 & 2.4 & 2.40 \\
\hline \multirow{2}{*}{3} & $\bar{x}$ & 9.6 & 12.0 & 22.3 & 29.8 & 921 & 1.92 \\
\hline & CV (\%) & 11.0 & 7.0 & 14.6 & 12.0 & 1.9 & 1.90 \\
\hline \multirow{2}{*}{4} & $\overline{\mathrm{x}}$ & 5.6 & 11.3 & 5.1 & 18.4 & 931 & 1.94 \\
\hline & CV (\%) & 17.5 & 15.9 & 12.4 & 15.6 & 4.9 & 4.90 \\
\hline \multirow{2}{*}{5} & $\overline{\mathrm{x}}$ & 15.9 & 18.5 & 33.9 & 41.1 & 907 & 2.10 \\
\hline & CV (\%) & 10.0 & 4.4 & 9.2 & 6.5 & 3.3 & 3.30 \\
\hline \multirow{2}{*}{6} & $\overline{\mathrm{x}}$ & 7.6 & 13.9 & 6.7 & 26.7 & 972 & 2.25 \\
\hline & CV (\%) & 16.8 & 18.2 & 15.2 & 14.6 & 4.9 & 4.90 \\
\hline \multirow{2}{*}{7} & $\overline{\mathrm{x}}$ & 14.6 & 15.7 & 28.0 & 37.2 & 926 & 2.14 \\
\hline & CV (\%) & 10.4 & 9.6 & 18.6 & 15.5 & 4.1 & 4.10 \\
\hline \multirow{2}{*}{8} & $\overline{\mathrm{x}}$ & 5.5 & 12.9 & 5.7 & 21.2 & 980 & 2.27 \\
\hline & CV (\%) & 17.8 & 9.6 & 19.3 & 16.9 & 5.1 & 5.10 \\
\hline \multirow{2}{*}{9} & $\overline{\mathrm{x}}$ & 21.3 & 22.8 & 40.5 & 43.5 & 966 & 2.51 \\
\hline & CV (\%) & 10.7 & 13.9 & 18.2 & 14.4 & 1.9 & 1.90 \\
\hline \multirow{2}{*}{10} & $\overline{\mathrm{x}}$ & 7.8 & 16.8 & 6.9 & 26.9 & 941 & 2.44 \\
\hline & CV (\%) & 18.9 & 10.5 & 10.0 & 16.1 & 9.1 & 9.10 \\
\hline \multirow{2}{*}{11} & $\overline{\mathrm{x}}$ & 16.7 & 17.9 & 29.5 & 35.9 & 968 & 2.51 \\
\hline & CV (\%) & 8.3 & 5.5 & 9.8 & 10.7 & 2.6 & 2.60 \\
\hline \multirow{2}{*}{12} & $\overline{\mathrm{x}}$ & 5.8 & 11.8 & 5.0 & 16.5 & 990 & 2.57 \\
\hline & CV (\%) & 12.2 & 16.8 & 14.7 & 9.6 & 7.1 & 7.10 \\
\hline \multirow{2}{*}{13} & $\bar{x}$ & 27.7 & 28.8 & 39.1 & 42.5 & 977 & 2.90 \\
\hline & CV (\%) & 6.8 & 6.4 & 12.8 & 10.6 & 2.7 & 2.70 \\
\hline \multirow{2}{*}{14} & $\bar{x}$ & 7.5 & 22.7 & 7.1 & 30.8 & 995 & 2.95 \\
\hline & CV (\%) & 19.7 & 9.2 & 12.3 & 15.2 & 2.6 & 2.60 \\
\hline \multirow{2}{*}{15} & $\bar{x}$ & 18.9 & 20.3 & 30.1 & 34.1 & 995 & 2.95 \\
\hline & CV (\%) & 9.0 & 6.1 & 8.2 & 6.6 & 1.8 & 1.80 \\
\hline \multirow{2}{*}{16} & $\bar{x}$ & 6.8 & 17.1 & 7.0 & 29.6 & 931 & 2.76 \\
\hline & CV (\%) & 13.6 & 10.8 & 9.3 & 17.2 & 7.6 & 7.60 \\
\hline \multirow{2}{*}{17} & $\bar{x}$ & 27.5 & 28.7 & 36.8 & 40.4 & 997 & 3.44 \\
\hline & CV (\%) & 9.5 & 6.8 & 18.7 & 12.9 & 4.3 & 4.30 \\
\hline \multirow{2}{*}{18} & $\overline{\mathrm{x}}$ & 6.0 & 19.2 & 4.0 & 20.8 & 1022 & 3.52 \\
\hline & CV (\%) & 17.3 & 13.4 & 14.5 & 18.4 & 6.6 & 6.60 \\
\hline \multirow{2}{*}{19} & $\bar{x}$ & 21.6 & 25.1 & 29.1 & 32.9 & 1066 & 3.68 \\
\hline & CV (\%) & 9.6 & 2.6 & 16.3 & 11.6 & 3.0 & 3.00 \\
\hline 20 & $\overline{\mathrm{x}}$ & 2.6 & 12.0 & 2.9 & 12.8 & 1015 & 3.50 \\
\hline & CV (\%) & 13.6 & 17.0 & 18.1 & 16.0 & 7.2 & 7.20 \\
\hline
\end{tabular}

Tr - Treatment; Stat - Statistics of average values (x) and coefficient of variation (cv); TS 2

$\mathrm{h}$ - Thickness swelling for $2 \mathrm{~h}$ period; TS $24 \mathrm{~h}$ - Thickness swelling for $24 \mathrm{~h}$ period; WA 2

$\mathrm{h}$ - Water absorption for $2 \mathrm{~h}$ period; WA $24 \mathrm{~h}$ - Water absorption for $24 \mathrm{~h}$ period; D - Density; CR - Compaction ratio

panels. High-density particleboards must have a density of $800 \mathrm{~kg} \mathrm{~m}^{-3}$ or higher, according to A208.1 (ANSI, 1999) and Iwakiri (2005).

As for the compaction ratio of the panels (Table 2), the mean values obtained were in the range of 1.84 to 3.68 , very similar to those found by Mendes et al. (2010), which obtained values in the range of 1.39 to 3.12 , for panels produced with sugarcane bagasse and Eucalyptus wood, and with adhesives phenol formaldehyde and urea formaldehyde. For both studies, the wide range of compaction ratio values is associated with the different densities of the materials used in the panels manufactured.

Normality and homogeneity tests of variances for the ANOVA residuals referring to the physical properties of panels were evaluated by Anderson-Darling, Bartlett and Levene methods (Christoforo et al., 2016). The ANOVA residuals, per response variable investigated, showed normal distribution. The variances of residuals between treatments were equivalent, and the residuals per property were independent. Table 3 presents the ANOVA results for the investigated physical properties.
P-values lower than or equal to 0.05 are underlined and considered significant at a significance level of 5\% (95\% confidence) over the evaluated property. When the interaction between the factors $(2: 2,3: 3)$ was considered as significant in any of the properties evaluated, main effects graphs were generated to support the interpretation of interaction effects.

In addition, the homogeneity in the panel production was also evaluated by the adjusted coefficient of determination $\left(\mathrm{R}^{2} \mathrm{adj}\right)$ for each property investigated. All physical properties evaluated showed sufficient homogeneity, with the exception of density, for which adjusted $\mathrm{R}^{2}$ reached $43.94 \%$.

Figure 1 shows the graphs of interaction between factors for the investigated physical properties, considered significant by ANOVA, according to Table 3 .

It can be observed, in Figures $1 \mathrm{~A}$ to $\mathrm{D}$, that the panels produced with the polyurethane adhesive based on castor oil (PU) had lower mean values of thickness swelling for 2 and $24 \mathrm{~h}$ periods, and water absorption for 2 and $24 \mathrm{~h}$ periods, when compared with panels produced with melamine formaldehyde adhesive (MF). The panels produced with the PU adhesive showed better physical performance.

In Figure 1E, panels produced with a higher percentage of adhesive $(13 \%)$ had lower mean values of water absorption for $2 \mathrm{~h}$ period compared with panels produced with $11 \%$ of adhesive. Panels produced with $13 \%$ adhesive showed better physical performance.
A.

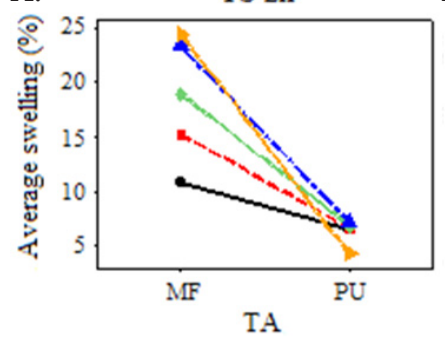

C.
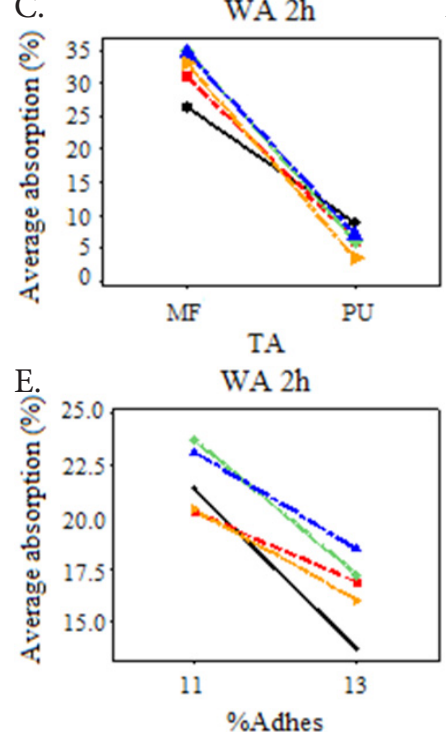

B.

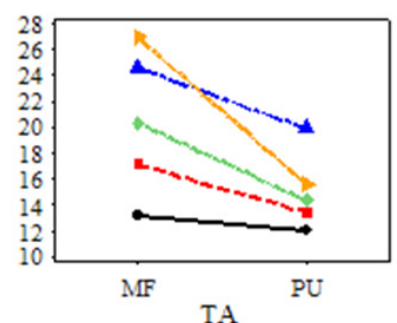

D.

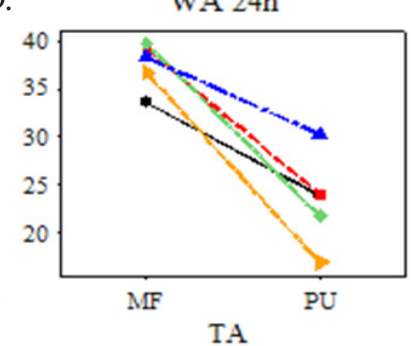

$\% \mathrm{OH}$ - Oat hulls percentage; TA - Type of adhesive; TS $2 \mathrm{~h}$ - Thickness swelling for $2 \mathrm{~h}$ period; TS $24 \mathrm{~h}$ - Thickness swelling for $24 \mathrm{~h}$ period; WA $2 \mathrm{~h}$ - Water absorption for $2 \mathrm{~h}$ period; WA $24 \mathrm{~h}$ - Water absorption for $24 \mathrm{~h}$ period; \% Adhes - Adhesive percentage

Figure 1. Interaction between factors for physical properties. Interaction \% OH x TA: for TS $2 \mathrm{~h}(\mathrm{~A})$; for TS $24 \mathrm{~h}(\mathrm{~B})$, for WA $2 \mathrm{~h}(\mathrm{C})$, for WA $24 \mathrm{~h}$ (D) and interaction $\% \mathrm{OH} \times \%$ Adhes for WA $2 \mathrm{~h}(\mathrm{E})$ 
Table 3. ANOVA results regarding the physical properties

\begin{tabular}{|c|c|c|c|c|c|c|}
\hline Factors and interactions & TS $2 \mathrm{~h}$ & TS $24 \mathrm{~h}$ & WA $2 \mathrm{~h}$ & WA $24 \mathrm{~h}$ & $\bar{D}$ & $\overline{C R}$ \\
\hline$\% \mathrm{OH}$ & $\underline{0.000}$ & $\underline{0.000}$ & 0.116 & 0.073 & $\underline{0.000}$ & $\underline{0.000}$ \\
\hline \% Adhes & $\overline{0.000}$ & $\overline{0.000}$ & $\underline{0.000}$ & $\underline{0.000}$ & $\overline{0.070}$ & $\overline{0.107}$ \\
\hline TA & 0.000 & 0.000 & 0.000 & 0.000 & 0.500 & 0.764 \\
\hline$\% \mathrm{OH} \times \%$ Adhes & 0.261 & 0.093 & $\underline{0.019}$ & 0.238 & 0.255 & 0.272 \\
\hline$\% \mathrm{OH} \times \mathrm{TA}$ & 0.000 & $\underline{0.000}$ & 0.000 & $\underline{0.000}$ & 0.060 & 0.145 \\
\hline$\%$ Adhes $\times$ TA & 0.072 & 0.576 & 0.143 & 0.927 & 0.198 & 0.124 \\
\hline$\% \mathrm{OH} \times \%$ Adhes $\times \mathrm{TA}$ & 0.106 & 0.051 & 0.236 & 0.256 & 0.150 & 0.107 \\
\hline $\mathrm{R}^{2}$ adj (\%) & 96.25 & 89.87 & 93.50 & 81.08 & 43.94 & 94.97 \\
\hline
\end{tabular}

$\% \mathrm{OH}$ - Oat hulls percentage; \% Adhes - Adhesive percentage; TA - Type of adhesive; $\mathrm{R}^{2}$ adj - adjusted coefficient of determination of ANOVA; TS $2 \mathrm{~h}$ - Thickness swelling for $2 \mathrm{~h}$ period; TS $24 \mathrm{~h}$ - Thickness swelling for $24 \mathrm{~h}$ period; WA $2 \mathrm{~h}$ - Water absorption for $2 \mathrm{~h}$ period; WA $24 \mathrm{~h}$ - Water absorption for $24 \mathrm{~h}$ period; D - Density; CR - Compaction ratio

\section{Conchusions}

1. The panels were classified as high-density (above $800 \mathrm{~kg} \mathrm{~m}^{-3}$ ).

2. Most of the treatments evaluated met at least one of the requirements of the standards consulted.

3. Panels produced with polyurethane adhesive based on castor oil showed better physical performance than panels produced with melamine formaldehyde adhesive.

4. The panels with 75 and $100 \%$ oat hull particles had higher densities as well as lower physical performances than panels with 0,25 and $50 \%$ of oat hull particles.

\section{ACKNOWLeDgments}

The authors are grateful to the Coordination for the Improvement of Higher Education Personnel (CAPES) for the support to the study.

\section{Literature Cited}

ABNT - Associação Brasileira de Normas Técnicas. NBR 14.810-2. Chapas de madeira aglomerada. Rio de Janeiro: ABNT, 2006. 51p. ANSI - American National Standard Institute. A208.1: Particleboard. Gaithersburg: Composite Panel Association, 1999. 13p.

Bertolini, M. S.; Nascimento, M. F. do; Christoforo, A. L.; Lahr, F. A. R. Painéis de partículas provenientes de rejeitos de Pinus sp. tratado com preservante CCA e resina derivada de biomassa. Revista Árvore, v.38, p.339-346, 2014. https://doi.org/10.1590/ S0100-67622014000200014

BS - British Standard. EN 312: Particleboards - specifications. London: BS, 2003. 12p.

Christoforo, A. L.; Nascimento, M. F. do; Panzera, T. H.; Ribeiro Filho, S. L. M.; Rocco, F. A. L. Homogeneous Pinus sp. particle boards reinforced with laminated composite materials. Engenharia Agrícola, v.36, p.558-565, 2016. https://doi.org/10.1590/18094430-Eng.Agric.v36n3p558-565/2016

Cravo, J. C. M.; Sartori, D. de L.; Gonzalo, M.; Schmidt, G. M.; Balieiro, J. C. de C.; Fiorelli, J. Effect of density and resin on the mechanical, physical and thermal performance of particleboards based on cement packaging. Construction and Building Materials, v.151, p.414-421, 2017. https://doi.org/10.1016/j. conbuildmat.2017.06.084

FAO - Food and Agriculture Organization of the United Nations. Statistics 2016: Forestry production and trade. Available on: <http://www.fao.org/faostat/en/\#data/FO>. Access on: Apr. 2018.
Ferro, F. S.; Almeida, T. H. de; Almeida, D. H. de; Christoforo, A. L.; Lahr, F. A. R. Physical properties of OSB panels manufactured with CCA and CCB treated Schizolobium amazonicum and bonded with castor oil based polyurethane resin. International Journal of Materials Engineering, v.6, p.151-154, 2016. https:// doi.org/10.5923/j.ijme.20160605.02

Fiorelli, J.; Christoforo, A. L.; Lahr, F. A. R.; Nascimento, M. F. do; Curtolo, D. D.; Sartori, D. de L.; Belini, U. L. Painéis de partículas monocamadas fabricados com resíduo de madeira e fibra de coco verde. Scientia Forestalis, v.43, p.175-182, 2015.

Gava, M.; Muzel, S. D.; Lima, L. R. de; Barbosa, J. C.; Garcia, J. N.; Ferreira, B. S.; Servolo Filho, H. J.; Bernardes, M. S.; Araújo, V. A. de. Production of particleboards from Hevea brasiliensis clones and castor oil-based polyurethane resin. BioResources, v.10, p.68966905, 2015. https://doi.org/10.15376/biores.10.4.6896-6905

IBGE - Instituto Brasileiro de Geografia e Estatística. Levantamento sistemático da produção agrícola - Safra de 2016. Available on: $<$ https://sidra.ibge.gov.br/home/lspa/brasil>. Access on: Jun. 2017.

Iwakiri, S. Painéis de madeira reconstituída. Curitiba: FUPEF, 2005. $247 \mathrm{p}$.

Macedo, L. B. de; Ferro, F. S.; Varanda, L. D.; Cavalheiro, R. S.; Christoforo, A. L.; Lahr, F. A. R. Propriedades físicas de painéis aglomerados de madeira produzidos com adição de película de polipropileno biorientado. Revista Brasileira de Engenharia Agrícola e Ambiental, v.19, p.674-679, 2015. https://doi. org/10.1590/1807-1929/agriambi.v19n7p674-679

Machado, N. A. F.; Furtado, M. B.; Parra-Serrano, L. J.; Parente, M. de O. M.; Fiorelli, J.; Savastano Júnior, H. Painéis aglomerados fabricados com resíduos do coco babaçu. Revista Brasileira de Ciencias Agrárias, v.12, p.202-209, 2017. https://doi. org/10.5039/agraria.v12i2a5434

Mendes, R. F.; Mendes, L. M.; Abranches, R. A. S.; Santos, R. C. dos; Guimarães Júnior, J. B. Painéis aglomerados produzidos com bagaço de cana em associação com madeira de eucalipto. Scientia Forestalis, v.38, p.285-295, 2010.

Nascimento, M. F. do; Christoforo, A. L.; Fiorelli, J.; Varanda, L. D.; Macedo, L. B. de; Lahr, F. A. R. Roughness study on homogeneous layer panels manufactured from treated wood waste. Acta Scientiarum. Technology, v.39, p.27-32, 2017. https://doi. org/10.4025/actascitechnol.v39i1.29438

Samlaic, J. Os atuais problemas e as possibilidades dos adesivos para madeira. Revista da Madeira, v.1, p.7-10, 1983.

Silva, D. A. L.; Lahr, F. A. R.; Varanda, L. D.; Christoforo, A. L.; Ometto, A. R. Environmental performance assessment of the melamine-urea-formaldehyde (MUF) resin manufacture: A case study in Brazil. Journal of Cleaner Production, v.96, p.299-307, 2015. https://doi.org/10.1016/j.jclepro.2014.03.007 
Varanda, L. D.; Christoforo, A. L.; Almeida, D. H. de; Silva, D. A. L. da; Panzera, T. H.; Lahr, F. A. R. Evaluation of modulus of elasticity in static bending of particleboards manufactured with Eucalyptus grandis wood and oat hulls. Acta Scientiarum. Technology, v.36, p.405-411, 2014. https://doi.org/10.4025/actascitechnol.v36i3.21077 Varanda, L. D.; Nascimento, M. F. do; Christoforo, A. L.; Silva, D. A. L. da; Lahr, F. A. R. Oat hulls as addition to high density panels production. Materials Research, v.16, p.1355-1361, 2013. https:// doi.org/10.1590/S1516-14392013005000131
Vidil, L.; Fiorelli, J.; Bilba, K.; Onésippe, C.; Arsène, M. A.; Savastano Junior, H. Thermal insulating particleboards reinforced with coconut leaf sheaths. Green Materials, v.4, p.31-40, 2016. https:// doi.org/10.1680/jgrma.15.00029

Weber, C.; Iwakiri, S. Utilização de resíduos de compensados, MDF e MDP para produção de painéis aglomerados. Ciência Florestal, v.25, p.405-413, 2015. https://doi.org/10.5902/1980509818460

Webster, F. H. Oats chemistry and technology. Saint Paul: American Association of Cereal Chemists, 1986. 122p. 